\title{
Zmiany w jakości kształcenia akademickiego w dobie pandemii COVID-19
}

\author{
Changes in the quality of academic education in the time \\ of the COVID-19 pandemic
}

\begin{abstract}
Streszczenie
System szkolnictwa w Polsce przeszedł w pierwszym okresie pandemii koronawirusa i w warunkach konieczności prowadzenia nauczania zdalnego przyspieszony proces wdrażania rozwiązań edukacji na odległość. Zadaniem, które sobie wyznaczyły uczelnie wyższe w dobie panującej pandemii, było utrzymanie jakości kształcenia na istniejącym poziomie, przy jednoczesnym zapewnieniu bezpieczeństwa studentom i wykładowcom. Zasadniczym celem opracowania jest zobrazowanie zmian w procesie kształcenia akademickiego, które nastąpiły w czasie pandemii COVID-19. W niniejszym artykule wskazano na specyficzne cechy kształcenia zdalnego, wskazując jego pozytywne i negatywne strony. Do realizacji założonego celu posłużyła kwerenda literatury krajowej i zagranicznej z zakresu prezentowanej problematyki badawczej, jak też analiza wtórnych źródeł informacji, głównie raportów z badań dotyczących kształcenia zdalnego w czasie pandemii. $\mathrm{Z}$ przeprowadzonych analiz wynika, że wymuszone przeniesienie edukacji na platformy wirtualne przyniosło pewne korzyści, ale i spowodowało szereg niekorzystnych zmian. Dotychczasowe doświadczenia edukacyjne w czasie pandemii pokazały, że przeniesienie tej formy
\end{abstract}

1 Gabriela Czapiewska, Instytut Geografii Społeczno-Ekonomicznej i Turystyki, Akademia Pomorska w Słupsku, Polska, e-mail: gabriela.czapiewska@apsl.edu.pl; ORCID ID: https://orcid. org/0000-0002-5638-9831. 
weryfikacji efektów uczenia się do cyberprzestrzeni nastręczało poważnych problemów - nie tyle studentom, co prowadzącym zajęcia. Edukacja zdalna stwarza nadzieję na dopasowanie technik nauczania do potrzeb studentów, a także na zmuszenie wykładowców do podniesienia jakości swoich zajęć, również od strony merytorycznej. Techniki kształcenia na odległość stają się więc integralną częścią procesu edukacji. Podjęte w artykule zagadnienia mogą stanowić punkt wyjścia do dalszych pogłębionych badań.

\section{Słowa kluczowe:}

pandemia COVID-19, edukacja, kształcenie zdalne, jakość kształcenia, e-learning

\section{Abstract}

Through the first period of the coronavirus pandemic, and in the need to teach remotely the education system in Poland underwent the accelerated process of implementation of distance learning solutions. The task that universities set themselves in the era of the prevailing pandemic was to maintain the quality of education at the existing level, while ensuring the safety of students and lecturers. The main aim of the study is to illustrate the changes in the academic education process that occurred during the COVID-19 pandemic. This article highlights the specific features of distance learning, pointing to its positive and negative sides. To achieve the assumed goal, a query of domestic and foreign literature in the field of the presented research issues was used, as well as an analysis of secondary sources of information, mainly reports on remote education research during the pandemic. The analyzes show that the forced transfer of education to virtual platforms brought some benefits, but also resulted in a number of unfavorable changes. The educational experience so far during the pandemic has shown that the transfer of this form of verification of learning outcomes to cyberspace posed serious problems - not so much for students, but for teachers. Remote education offers hope for matching teaching techniques to the needs of students, as well as for forcing lecturers to improve the quality of their classes, also in terms of content. Distance learning techniques are therefore becoming an integral part of the education process. The issues discussed in the article may constitute a starting point for further in-depth research.

\section{Keywords:}

pandemic COVID-19, education, higher education, quality of education, e-learning 


\section{WSTĘP}

W dynamikę zmian i sytuacji nieprzewidywalnych, z którymi mierzy się współczesny człowiek, wpisuje się doświadczana obecnie przez ludzi na całym świecie pandemia COVID-19. Wywiera ona ogromny wpływ na wszystkie dziedziny życia i funkcjonowania człowieka na każdym etapie jego rozwoju, w tym również na proces edukacji (Sułkowski, 2020). Okres pandemii to wielkie wyzwanie dla całego środowiska edukacyjnego, które musiało dostosować się do nowych warunków pracy w formie kształcenia online. Szczególną rolę w tym zakresie odegrały nowoczesne technologie, dzięki którym możliwe i realne na dużą skalę stało się wdrożenie nauki zdalnej. Pandemia koronawirusa zapoczątkowała więc eksperyment z nauczaniem zdalnym, przeprowadzony na skalę społeczną w odniesieniu do wszystkich grup osób uczących się, niezależnie od wieku i dyscypliny.

Kształcenie zdalne na poziomie wyższym nie jest niczym nowym. Od ponad 50 lat działają uniwersytety otwarte, a wraz z upowszechnieniem Internetu ta forma kształcenia stała się nieodłącznym elementem oferty edukacyjnej większości uczelni (Kraśniewski, 2020; Łaszczyk, 2020). Nowym aspektem jest natomiast skala kształcenia zdalnego, realizowanego z wykorzystaniem Internetu (kształcenia online), wymuszona warunkami, w których przyszło nam funkcjonować już od ponad roku (Gálik, 2020). Podczas pierwszej fali pandemii niejako „awaryjnie” przeniesiono do cyberprzestrzeni formy kształcenia realizowane dotychczas w sposób tradycyjny (proces ten określany jest w literaturze jako emergency online learning). Z czasem jednak wprowadzano na uczelniach kształcenie mieszane hybrydowe, obejmujące nadal znaczny udział zajęć prowadzonych zdalnie.

Zadaniem uczelni wyższych jest zapewnienie wysokiej jakości kształcenia niezależnie od metody nauczania. Celem, który sobie wyznaczyły w dobie panującej pandemii, było niewątpliwie utrzymanie jakości kształcenia na istniejącym poziomie, przy jednoczesnym zapewnieniu bezpieczeństwa studentom i wykładowcom. Wytyczony kierunek działań osiągnąć można poprzez umiejętną organizację zajęć, ukierunkowaną na efektywne wykorzystanie dostępnych możliwości. Zasadniczym celem opracowania jest zobrazowanie zmian w procesie kształcenia akademickiego, jakie nastąpiły w czasie pandemii COVID-19. W niniejszym artykule wskazano na specyficzne cechy kształcenia zdalnego, które istotnie różni się od nauczania bezpośredniego (stacjonarnego), wskazując jego pozytywne i negatywne strony. Do realizacji założonego celu posłużyła kwerenda literatury krajowej i zagranicznej z zakresu prezentowanej problematyki badawczej, jak też analiza wtórnych źródeł informacji, głównie raportów z badań dotyczących 
kształcenia zdalnego w czasie pandemii. Podjęte w artykule zagadnienia mogą stanowić punkt wyjścia do dalszych pogłębionych badań.

\section{EDUKACJA W CZASIE PANDEMII}

Prowadzenie edukacji w dobie pandemii (od marca 2020 roku) okazało się jednym z trudniejszych wyzwań, z jakim musieli się zmierzyć zarówno wykładowcy, jak i studenci. Zdalne nauczanie wymagało od pracowników prowadzących zajęcia dydaktyczne rozszerzenia kompetencji w zakresie cyfrowych sposobów komunikacji. Wielu z nich odczuwało z tego powodu presję, a także dystans (spowodowany lękiem i brakiem umiejętności) wobec wykorzystywania narzędzi cyfrowych. Od dawna wiadomo, że umiejętności nauczyciela związane z tym, jak uczyć, stanowią fundamentalny czynnik dla osiągnięć studentów. Znajduje to potwierdzenie w licznych badaniach empirycznych i wprost jest wymieniane jako element niezbędny, a zarazem względnie kontrolowalny, wysokiej jakości kształcenia (Stronge, 2010).

Kształcenie zdalne, przy wykorzystaniu specjalnych narzędzi, platform edukacyjnych nie jest zjawiskiem zupełnie nowym (Latchem i Jung, 2010; Burns, 2011; Gurba i Rimanelli, 2018). E-learning pojawił się w Polsce ponad dekadę temu i był wykorzystywany w nauczaniu na różnych poziomach kształcenia, także w szkołach wyższych. Jednakże możliwość wykorzystania e-learningu w procesie kształcenia na uczelniach jest w naturalny sposób ograniczona (Kozłowska, 2017; Mokwa-Tarnowska, 2019; Maleńczyk i Gładysz, 2019). Wiele zajęć, w szczególności takich jak laboratoria czy warsztaty, gdzie wykorzystuje się specjalistyczne urządzenia, przekazywanie studentom wiedzy i umiejętności przy pomocy zdalnych form nauczania jest bardzo trudne, jeśli wręcz nie niemożliwe. Poziom sprawności lub występujących problemów w trakcie procesu zdalnego nauczania jest bez wątpienia związany z pewnymi umiejętnościami, które nauczyciele akademiccy mogli ukształtować w wyniku wcześniejszych doświadczeń (Bożykowski i in., 2021). W związku z powyższym część wykładowców dość szybko zaadaptowała się do istniejących warunków, ponieważ posiadała doświadczenie w prowadzeniu zajęć zdalnych, a uczelnie dysponowały ogólnouczelnianymi rozwiązaniami platformami e-learningowymi i oprogramowaniem do komunikacji synchronicznej (Piwowarska, 2020).

Nauczanie zdalne to nie tylko aspekty techniczne. Podstawowe idee e-learningu dotyczą ważnych kwestii metodycznych, w tym sposobu przygotowania materiałów dydaktycznych, aktywizowania studentów oraz ewaluacji wiedzy. 
W przypadku prowadzenia zajęć zdalnych jest niezwykle ważne, aby z góry określić sposoby i zasady komunikacji ze studentami. Prowadzi to zarówno do zwiększenia efektywności, jak i stymuluje działania studentów.

Nieoczekiwane okoliczności zewnętrzne wytworzyły zatem nową płaszczyznę do prowadzenia badań nad stopniem przygotowania i oceną radzenia sobie w zaistniałej sytuacji z edukacją na odległość (Gurba, 2020). Oczywiście badania nad wszelkimi aspektami jakości kształcenia w formie zdalnej mają długą historię, ale myśl o budowie efektywnej pedagogiki cyfrowej zyskała w roku naznaczonym pandemią nowy impuls rozwojowy (Robertson, 2020). Sytuacja inspirować może do budowy przemyślanych planów kontroli jakości zarówno treści przekazywanych zdalnie, jak i procedur, metod i technik ich udostępniania studentom. Kształcenie zdalne stworzyło zatem wymóg nie tylko powszechnego dostępu do narzędzi oraz odpowiedniego poziomu kompetencji cyfrowych, ale także innej metodyki pracy ze studentami. Do realizacji wielu celów dydaktycznych (wykład, częściowo ćwiczenia i projekty) wystarczająca była forma asynchroniczna, polegająca na dostarczaniu materiałów (również w formie nagrań wideo, linków do źródeł) oraz organizowaniu innych aktywności (zadania, projekty, testy do wykonania w określonym czasie), przy czym studenci i prowadzący kontaktują się poprzez pocztę elektroniczną, forum lub inne formy asynchroniczne. Bezdyskusyjna jest kwestia realnego oszacowania wkładu pracy studenta do zajęć w trybie zdalnym (Piwowarska, 2020).

Koniecznością stało się zmodyfikowanie sposobów nauczania do nowych warunków. Zmiany te były wyzwaniem szczególne trudnym w przypadku nauki przedmiotów specjalistycznych oraz praktycznych. Pojawiła się także potrzeba przygotowania nowych materiałów dydaktycznych dostosowanych do koncepcji nauczania online. Z punktu widzenia nauczyciela akademickiego wymagało to często znacznie większego nakładu pracy, aby materiał zwykle omawiany i poddawany dyskusji w trybie uczenia stacjonarnego przełożyć na odpowiednie narzędzia danej platformy do nauki zdalnej. Jak podkreśla B. Means i in. (2014), nie sama technologia, ale jej interakcja ze sposobem implementacji, kontekstem oraz celami kształcenia (efekty uczenia się) decyduje o wyniku końcowym, zarówno po stronie nauczyciela, jak i studenta.

Do głównych modeli edukacji sięgających po rozwiązania cyfrowe należą:

- edukacja cyfrowa jako wsparcie kształcenia tradycyjnego;

- edukacja mieszana, łącząca wykorzystanie edukacji cyfrowej oraz kształcenia tradycyjnego;

- edukacja cyfrowa wspierana kształceniem tradycyjnym;

- edukacja cyfrowa w czystej formie (Plebańska, 2020). 
Edukacja cyfrowa, dobrze zaprojektowana i przemyślana, przynosi wiele korzyści. Do jej zalet zaliczyć należy m.in.:

- „zwiększenie efektywności procesów edukacyjnych, sprzyjanie rozwojowi kompetencji przyszłości;

- uwalnianie kreatywności indywidualnej, a jednocześnie uczenie współpracy w grupie;

- wspieranie kreowania indywidualnych ścieżek rozwoju;

- wszechstronny rozwój, wyrównywanie edukacyjnych dysproporcji społecznych, bowiem niezależnie od miejsca zamieszkania jest szansą edukacyjną dla osób z ubogich rodzin;

- [fakt, że] zapewnia możliwość edukacji globalnej, uniezależnia proces edukacyjny od czasu, miejsca i przestrzeni;

- [możliwość] zapewnienia dostępu do dzieł sztuki, wiedzy historycznej, zasobów muzealnych w formie atrakcyjnej dla odbiorcy;

- wyrównywanie szans rozwojowych osób o specjalnych potrzebach edukacyjnych,

- umożliwianie uczniom stałego dostępu do wiedzy” (Plebańska, 2020, s. 39).

Powszechnie zakłada się, że kształcenie zdalne jest z definicji gorsze pod względem jakości aniżeli realizowane w formie stacjonarnej. E. Gruszczyńska (2020) podkreśla, że jeżeli tego typu stwierdzenie pozostanie po pandemii, to może na długi okres kształtować nie tylko postawę kadry akademickiej i studentów, ale i wpływać na wymogi formalne wobec programów studiów. Zdaniem A. Koludo (2020) istotą powodzenia kształcenia zdalnego są zasadniczo trzy elementy: możliwości techniczne (sprzęt, dobry dostęp do Internetu, oprogramowanie zarządzające zdalną edukacją), zasoby edukacyjne oraz umiejętności kadry pedagogicznej. Podkreślić należy, iż proces kształcenia na odległość w czasie pandemii COVID-19 wzmocnił kompetencje cyfrowe wykładowców (Schleicher, 2020). Z czasem zaczęli oni nawet dostrzegać korzyści z edukacji realizowanej online.

Pandemia COVID-19 ujawniła kilka kwestii na temat edukacji zdalnej: „po pierwsze, wiele rzeczy się da, kiedy trzeba. Po drugie, wielu rzeczy się nie da, nawet jak się bardzo chce. Po trzecie, trzeba jeszcze sporo badań i doświadczenia, aby sensownie wykorzystać technologię w dydaktyce, ale już wiadomo, że blended learning ma przyszłość” (Jemielniak, 2020, s. 33). 


\section{KSZTAŁCENIE ZDALNE - POZYTYWNE I NEGATYWNE STRONY}

Czas pandemii obfituje w badania nie tylko z zakresu medycyny czy socjologii, ale też edukacji (m.in. Buchner i in., 2020; Centrum Cyfrowe, 2020; Czapliński i in., 2020; Długosz, 2020; Doucet i in., 2020; Jaskulska i Jankowiak, 2020; Krauze-Sikorska i in., 2020; Plebańska i in., 2020; Ptaszek i in., 2020; Bożykowski i in., 2021). $Z$ analizy raportów wynika, że wymuszone przeniesienie edukacji na platformy wirtualne przyniosło pewne korzyści, ale i spowodowało szereg niekorzystnych zmian.

Do pozytywnych aspektów zaistniałej sytuacji zaliczyć można - pomijając oczywiste kwestie oszczędności czasu (pracowników i studentów) zużywanego na dojazdy - istotny rozwój nowych kompetencji pracowników i studentów. Wielu nauczycieli akademickich, w sposób wymuszony przez sytuację, dość szybko musiało opanować nowoczesne technologie. Sytuacja pandemii pozwoliła im na uaktywnienie i możliwość wykorzystania w praktyce (a także możliwość rozwoju) dotychczas sporadycznie wykorzystywanych kompetencji dydaktycznych (informatycznych). Dzięki zdalnej edukacji mogli je w sposób kreatywny wykorzystywać zarówno w jakości przygotowywanych zajęć, jak i materiałów oraz form ich przekazu (Zahorska, 2020). Zdaniem D. Jemielniaka (2020) statystyki wykorzystania platform do wideokonferencji pokazują, że w Polsce, podobnie jak na świecie, Zoom, Google Meet czy Microsoft Teams odnotowały bezprecedensowy skok liczby pobrań. Proces nie przebiegał łatwo, ale umiejętności używania tych platform do prowadzenia zajęć dydaktycznych nie da się oduczyć - i ogromną wartością dla nauczycieli jest obecnie to, że wielu z nich bez problemu jest już w stanie posłużyć się nimi, a także innymi narzędziami. Prowadzenie egzaminów oraz obrony prac licencjackich i magisterskich dodatkowo przyczyniły się do wykorzystywania technologii informacyjno-komunikacyjnych w formie, z jakiej do tej pory powszechnie nie korzystano.

W ogólnym bilansie zdecydowanie przeważają negatywne strony pandemii COVID-19. Pomijając tragiczny bilans ofiar i bezpośredni oraz pośredni wpływ zarówno na zdrowie publiczne, jak i na gospodarkę, dla edukacji i szkolnictwa wyższego wymuszone przejście na naukę zdalną było niesłychanie destrukcyjne. Nie bez znaczenia są też godziny spędzone na siedząco zarówno podczas zajęć, jak i przygotowywania się do nich (Chau i in., 2013), a także poczucie braku rozgraniczenia między pracą a życiem osobistym.

Kształcenie zdalne spowodowało szereg problemów, które zdaniem A. Kraśniewskiego (2020, s. 41) podzielić można na dwie grupy:

- problemy obiektywnie trudne do rozwiązania, związane z realizacją zajęć wymagających kontaktów międzyludzkich lub wykorzystania zasobów, 
które są dostępne jedynie na uczelni lub w jednostkach uczestniczących w procesie kształcenia; są one typowe dla programów obejmujących duży komponent zajęć praktycznych (studia na kierunkach lekarskich, inżynierskich, niektórych przyrodniczych czy ścisłych) i uwidoczniają się zwłaszcza na studiach o profilu praktycznym oraz studiach dualnych;

- problemy będące konsekwencją określonego sposobu realizacji kształcenia tradycyjnego, uwidoczniające się przy przejściu do kształcenia zdalnego, jak np. weryfikacja efektów kształcenia.

Wyzwaniem w trakcie pandemii była organizacja sesji egzaminacyjnych online w taki sposób, aby spełnić standardy i wymagania dotyczące procedury przeprowadzania egzaminów semestralnych. Problemem jest brak ujednolicenia w aspekcie używanych rozwiązań informatycznych do komunikacji synchronicznej i asynchronicznej, zarządzania procesem nauczania i przechowywania materiałów dydaktycznych. Spowodowało to, że w tym trudnym okresie uczelnie czy inne instytucje dydaktyczne stały się mocno narażone na wpływy twórców i sprzedawców oprogramowania.

Konteksty społeczne, które wymagają budowy zaufania, również bardzo trudno realizuje się zdalnie. Widać to wyraźnie także w edukacji. J. Kim (2011, s. 763) wskazuje, że „edukacja online może poskutkować utratą kontaktów międzyludzkich, brakiem interakcji twarzą w twarz i fizycznym dystansem wynikającym z tych czynników”. Studenci i wykładowcy zgodnie podkreślają, że edukacja akademicka to znacznie więcej niż przekazywanie wiedzy - to cenny networking i relacje międzyludzkie, a tych nie da się uzyskać równie łatwo zdalnie.

Dotychczasowe doświadczenia edukacyjne w czasie pandemii pokazały, że przeniesienie tej formy weryfikacji efektów uczenia się do cyberprzestrzeni nastręczało poważnych problemów - nie tyle studentom, co prowadzącym zajęcia (Urbaniec, 2020). Problem staje się szczególnie trudny, jeśli to przeniesienie dotyczy sprawdzianów, podczas których studenci nie mogą korzystać z materiałów źródłowych - książek, notatek, informacji dostępnych w Internecie. Zasadniczym problemem jest zapewnienie wiarygodności takiego sprawdzianu, tzn. zapewnienie, że osoba poddana takiemu sprawdzianowi jest rzeczywiście osobą, za którą się podaje, oraz że nie korzysta ona z niedozwolonych pomocy - materiałów, ale także pomocy osób trzecich. Możliwość korzystania w trakcie sprawdzianów z wszelkich notatek oraz Internetu może w pierwszym odruchu budzić sprzeciw. Zależy to jednak ponownie od tego, jakie efekty uczenia się w ten sposób weryfikujemy. Gdy chcemy sprawdzać wykorzystanie wiedzy oraz umiejętność korzystania ze źródeł, a takie m.in. cele kształcenia określa Polska Rama Kwalifikacji dla studiów wyższych, ta forma, o ile tylko będzie dobrze przygotowana 
od strony merytorycznej, może być wręcz preferowana (Gruszczyńska, 2020). Kształcenie z wykorzystaniem Internetu ma oczywiście pewną specyfikę, którą trzeba uwzględnić przy planowaniu i prowadzeniu zajęć. Jakość kształcenia online wynika przede wszystkim z ogromnego wysiłku, zaangażowania i elastyczności kadry oraz studentów wobec powszechnego braku alternatywy.

Wyniki badań zawarte w raportach dotyczących edukacji w czasie pandemii dowiodły, że w opinii wykładowców najpilniejsze byłoby przywrócenie tradycyjnej formy nauczania w przypadku zajęć praktycznych - warsztatów, pracowni i laboratoriów. Najrzadziej wskazywano w tym kontekście wykłady i lektoraty. Okazało się ponadto, że wykłady za pomocą narzędzi informatycznych są nie tylko możliwe, ale i skuteczne. Frekwencja w wielu przypadkach wzrosła, bo w wykładach uczestniczyli studenci niezależnie od swojego miejsca pobytu w kraju i za granicą (Cellary, 2020). Nie dziwi zatem fakt, że studenci uznają większą powszechną akceptację dla wykładów online niż ćwiczeń czy warsztatów. Jednym z czynników była łatwa dostępność, a student może przyjmować postawę raczej widza niż aktywnego uczestnika. Nastawiony na przekazanie wiedzy model kształcenia wykładowcy często starali się przenieść do wirtualnej rzeczywistości, zapominając o aktywizowaniu studentów. Niestety w rzeczywistości wirtualnej tradycyjny przekaz się nie sprawdza. Oprócz organizacji kształcenia zdalnego w układzie pionowym (zstępującym) nauczyciel-uczeń ważną rolę odgrywa taka organizacja procesu kształcenia, aby aktywować w możliwie skuteczny sposób komunikację w układzie poziomym: uczeń-uczeń. W obecnych czasach zagrożenia, kiedy podróże oraz kontakty między studentami są z natury ograniczone, współpraca zdalna może przynieść wymierne efekty (Topol, 2020). Osoby oceniające swoje warunki do pracy zdalnej jako bardzo dobre wskazywały, że prowadzone przez nie zajęcia zdalne były podobnie skuteczne jak zajęcia w sali pod kątem zdobywania przez studentów kompetencji założonych w programie nauczania i możliwości śledzenia postępów studentów, ale mniej skuteczne pod względem poziomu zaangażowania studentów i kontaktu z nimi podczas zajęć, a także efektywności egzaminowania. Prowadzenie zajęć w sali uważano za bardziej efektywny sposób osiągnięcia założonych efektów kształcenia, dlatego zajęcia ważne dla danego obszaru kształcenia były najczęściej wskazywane jako te, które powinny w pierwszej kolejności wrócić do trybu stacjonarnego.

Spowodowany wybuchem pandemii nieoczekiwany i nagły zakaz bezpośrednich kontaktów na uczelni między wykładowcami i studentami wymusił w środowisku akademickim konieczność głębszej refleksji nad sposobami kształcenia studentów. Zdaniem E. Piwowarskiej (2020), pomimo wielu błędów popełnianych 
przez nauczycieli akademickich w okresie pandemii, doświadczenia z obecnej sytuacji mogą znacząco poprawić jakość kształcenia na uczelniach wyższych. Przy czym dotyczy to zarówno warstwy metodycznej, jak i merytorycznej. Pandemia pokazała, że można uczyć inaczej, a dydaktyka w perspektywie czasu może przynieść korzyść całemu środowisku akademickiemu. Studenci, zadowoleni z prawidłowo prowadzonych zajęć zdalnych, już w tej chwili mocno lobbują za wprowadzeniem tych metod na stałe i stosowanie ich po pandemii. Całkowicie stacjonarny tryb studiowania zaczyna być postrzegany przez nich jako „archaiczny”.

Wydaje się, że - biorąc pod uwagę przedstawione obserwacje, a także prognozy rozwoju sytuacji epidemicznej - należałoby kontynuować wymuszony okolicznościami proces transformacji modelu kształcenia i, wykorzystując zdobyte doświadczenie, dokonać kolejnych istotnych zmian - przekształcić rozwiązania funkcjonujące w awaryjnym trybie online w wysokiej jakości kształcenie mieszane (blended learning). Polega na łączeniu technik samodzielnej pracy z materiałem na platformie edukacyjnej i asynchronicznej komunikacji z wykładowcą ze spotkaniami w formie tradycyjnej (lub zdalnej synchronicznej). Czasowy zdalny kontakt albo prowadzenie pewnych typów zajęć w tej formie i powierzanie studentom, siłą rzeczy, większej liczby zadań do samodzielnego wykonania pozwoli im na zyskanie pewności siebie, samodzielności w pierwszych naukowych działaniach, nauczy rozplanowania czasu, odpowiedzialności za terminowe wywiązanie się z poleceń, wreszcie samodyscypliny (Bartol, 2020).

Kształcenie zdalne stwarza też pole do wdrażania nowych, odmiennych od dotychczas stosowanych metod prowadzenia zajęć i realizacji eksperymentów w tym zakresie. Jako przykłady takich działań można wymienić: upowszechnienie modelu kształcenia odwróconego (flipped education), zwłaszcza jeśli ograniczenia sanitarne nie pozwolą na obecność dużych grup studentów w jednej sali, wykorzystanie przez prowadzących zajęcia informacji zwrotnej otrzymywanej od studentów w czasie rzeczywistym w trakcie zajęć, wykorzystanie narzędzi analityki edukacyjnej (learning analytics), m.in. do wspomagania indywidualizacji procesu kształcenia, czy nawet tak nowatorskie w polskich warunkach działania, jak egzaminy w formule take home (student dostaje do rozwiązania zadanie lub problem i rozwiązuje je samodzielnie $\mathrm{w}$ domu, a następnego dnia prezentuje rozwiązanie). Nowe technologie stwarzają zatem nowe możliwości. 


\section{PODSUMOWANIE}

Wprowadzone restrykcje w marcu 2020 roku wymusiły na uczelniach wyższych gwałtowne zmiany w trybie nauczania z docelowym całkowitym przejściem na nauczanie zdalne. Zarówno system szkolnictwa w Polsce, jak i poszczególne jego podmioty składowe nie były przygotowane do takiej transformacji. Konieczność szybkiego dostosowania się uczelni do nauczania zdalnego obnażyła wiele braków w systemie kształcenia z wykorzystaniem nowoczesnych narzędzi teleinformatycznych. Za mało jest wspólnych, ogólnouczelnianych rozwiązań technicznych i integracji systemów do nauczania zdalnego z innymi systemami uczelni. Ponadto brakuje jeszcze możliwości technicznych do realizacji pomysłów na przeprowadzenie niektórych zaawansowanych aktywności, które studenci mogliby wykonać poza siedzibą uczelni w trybie zdalnym.

W celu realizacji zdalnej edukacji tworzone były liczne rozwiązania informatyczne i narzędzia, w tym platformy wspierające procesy edukacyjne. Na tej podstawie można by sformułować tezę, że sytuacja pandemii COVID-19 umożliwiła pełne wykorzystanie dotychczasowych kompetencji dydaktyczno-informatycznych, zarówno wykładowców, jak i studentów, a jednocześnie narzędzi dostępnych w codziennej rzeczywistości nauczania i uczenia się w czasie izolacji. Panująca pandemia udowodniła, że bardzo wiele przedsięwzięć edukacyjnych na uczelniach wyższych można zrealizować w formie zdalnej. Sukcesywnie wzrasta istota i waga tej formy kształcenia w świadomości środowiska akademickiego. Mimo niewątpliwych zalet, które ujawniły się już wcześniej (m.in. dostępność, elastyczność, oszczędność), a w obecnej światowej sytuacji urosły do rangi koła ratunkowego edukacyjnych działań, zdalny model funkcjonowania systemu edukacji, przy założeniu wysokiego stopnia zaangażowania się w działania obu stron procesu - nauczycieli akademickich i studentów - może służyć nauczaniu, kształceniu zdecydowanie mniej (Bartol, 2020).

Edukacja zdalna stwarza nadzieję na dopasowanie technik nauczania do potrzeb studentów, a także na zmuszenie wykładowców do podniesienia jakości swoich zajęć, również od strony merytorycznej. Techniki kształcenia na odległość stają się więc integralną częścią procesu edukacji. Niewątpliwie mechanizm kształcenia zdalnego powinien być projektowany od podstaw i stać się trwałym elementem uzupełniającym (a nie zastępującym) edukację w formie stacjonarnej na uczelni. Ewolucyjne zmiany zatem już się dokonują. Jak podkreśla K. Bartol (2020), pewne jest, że proces nauczania i kształcenia pozostanie jednym z najważniejszych społecznych działań człowieka. 
Obecna sytuacja związana z czasem pandemii COVID-19 wymaga także ponownego przemyślenia kształcenia i doskonalenia zawodowego nauczycieli oraz wzmocnienia zawodu nauczyciela, na co zwraca się bardzo dużą uwagę w Białej Księdze UNESCO Save Our Future: Averting an Education Catastrophe for the World's Children („Ocalmy naszą przyszłość: Zapobieganie katastrofie edukacyjnej dzieci na świecie”). Podniesienie jakości edukacji nauczycieli i ich pracy, wzmocnienie zawodu nauczyciela oraz wsparcie, które powinno być kierowane w ich stronę, to priorytetowe działania mające na celu wprowadzenie zmian w edukacji na świecie w ciągu najbliższych kilku miesięcy (Madalińska-Michalak, 2020). Wydaje się, że w nauczaniu po pandemii, jak zawsze, sprawdzi się starożytna zasada złotego środka.

\section{Bibliografia}

Bartol, K. (2020). Nihil novi sub sole? Stare pytania. Jakie odpowiedzi? W: Nauczanie po pandemii. Nowe pytania czy nowe odpowiedzi na stare pytania? (s. 9-13). Warszawa: Instytut Problemów Współczesnej Cywilizacji im. Marka Dietricha.

Bożykowski, M., Izdebski, A., Jasiński, M., Konieczna-Sałamatin, J. (2021). Nauczanie w dobie pandemii i perspektywa powrotu do normalności. Raport. Warszawa: Pracownia Ewaluacji Jakości Kształcenia Uniwersytetu Warszawskiego.

Buchner, A., Majchrzak, M., Wierzbicka, M. (2020). Badanie edukacji zdalnej w czasie pandemii. Pobrane z: https://centrumcyfrowe.pl/edukacja-zdalna/.

Burns, M. (2011). Distance Education for Teacher Training: Modes, Models, and Methods. Washington, DC: Education Development Center, Inc.

Cellary W. (2020). Edukacja w świetle pandemii. W: Nauczanie po pandemii. Nowe pytania czy nowe odpowiedzi na stare pytania? (s. 15-23). Warszawa: Instytut Problemów Współczesnej Cywilizacji im. Marka Dietricha.

Centrum Cyfrowe (2020). Edukacja zdalna w czasie pandemii. Raport z badań. Pobrane z: https:// centrumcyfrowe.pl/edukacja-zdalna/.

Chau, J. Y., Grunseit, A. C., Chey, T., Stamatakis, E., Brown, W. J., Matthews, C. E., Bauman, A. E., van der Ploeg, H. P. (2013). Dailysittingtime and all-causemortality: a meta-analysis, PloS one, 8 (11), e80000. Pobrane z: https://doi.org/10.1371/journal. pone.0080000.

Czapliński, P. i in. (2020). Raport Edukacja. Między pandemiq COVID-19 a edukacjq przyszłości. Pobrane z: https://oees.pl/wp-content/uploads/2020/08/Raport-edukacja. pdf.

Długosz, P. (2020). Raport z badań „Krakowscy studenci w sytuacji zagrożenia pandemiq koronawirusa”. Kraków: Instytut Filozofii i Socjologii Uniwersytetu Pedagogicznego im. Komisji Edukacji Narodowej w Krakowie. Pobrane z: http://rep. up.krakow.pl/ xmlui/handle/11716/7036.

Doucet, A., Netolicky, D., Timmers, K., Tuscano, J. (2020). Thinking about Pedagogy in 
an Unfolding Pandemic, An Independent Report on Approaches to Distance Learning During COVID19 School Closures. Pobrane z: https://issuu.com/ educationinternational/docs/2020_research_covid-19_eng.

Gálik, S. (2020). Philosophical Reflection of the Influence of Digital Media on Current Education, Edukacja medialna (Mediaobrazovanie), 2020, 60 (1), s. 100-106. DOI: 10.13187/ me.2020.1.100.

Gruszczyńska, E. (2020). Kształcenie wyższe na odległość: jednak w poszukiwaniu nowych odpowiedzi na stare pytania. W: Nauczanie po pandemii. Nowe pytania czy nowe odpowiedzi na stare pytania? (s. 25-31). Warszawa: Instytut Problemów Współczesnej Cywilizacji im. Marka Dietricha.

Gurba, K. (2020). Edukacja na odległość w czasie pandemii w ocenie dyrektorów szkół. W: N. G. Pikuła, K. Jagielska, J. M. Łukasik (red.), Wyzwania dla edukacji w sytuacji pandemii COVID-19. (s. 151-178). Kraków: Wydawnictwo Scriptum.

Gurba, K., Rimanelli, M. (2018). Quality Measures, Human Factor and Failures of e-Learning, Labor et Educatio, 6, s. 37-59.

Jaskulska, S. Jankowiak, B. (2020). Kształcenie na odległość w Polsce w czasie pandemii COVID-19. Pobrane z: https://sites.google.com/view/ksztalcenie-pandemia-raport.

Jemielniak, D. (2020). Zdalne nauczanie - blended, nie single Malt. W: Nauczanie po pandemii. Nowe pytania czy nowe odpowiedzi na stare pytania? (s. 33-37). Warszawa: Instytut Problemów Współczesnej Cywilizacji im. Marka Dietricha.

Kim, J. (2011). Developing an Instrument to Measure Social Presence in Distance Higher Education. British Journal of Educational Technology, 42 (5), s. 763-777.

Koludo, A. (2020). Strategie kształcenia na odległość. W: J. Pyżalski (red.), Edukacja w czasach pandemii wirusa COVID-19. Z dystansem o tym, co robimy obecnie jako nauczyciele. Warszawa: EduAkcja, s. 43-50.

Kozłowska, J. (2017). E-learning jako forma doskonalenia studentów uczelni wyższych. Rynek - Społeczeństwo - Kultura, 1 (22), s. 41-48.

Kraśniewski, A. (2020). O jakości kształcenia w czasach Covid-19: stare odpowiedzi na nowe pytania? W: Nauczanie po pandemii. Nowe pytania czy nowe odpowiedzi na stare pytania? (s. 39-50). Warszawa: Instytut Problemów Współczesnej Cywilizacji im. Marka Dietricha.

Krauze-Sikorska, H., Klichowski, M., Jaskulska, S., Jankowiak, B., Sikorska, J., Koziarski, J. (2020). Twoja lekcja w przyszłości. Jak wyobrażasz sobie naukę w szkole po pandemii COVID-19? Raport z badania ankietowego. VULCAN. Pobrane z: https://sites. google. $\mathrm{com} /$ view/twoja-lekcja-w-przyszlosci.

Latchem, C., Jung, I. (2010). Distance and blended learning in Asia. New York: Routledge. Łaszczyk, J. (2020). Edukacja zdalna - szansa czy konieczność? W: Nauczanie po pandemii. Nowe pytania czy nowe odpowiedzi na stare pytania? (s. 65-72). Warszawa: Instytut Problemów Współczesnej Cywilizacji im. Marka Dietricha.

Madalińska-Michalak, J. (2020). Nauczanie zdalne i edukacja nauczyciela - wyzwania. W: N. G. Pikuła, K. Jagielska, J. M. Łukasik (red.), Wyzwania dla edukacji w sytuacji pandemii COVID-19 (s. 13-29). Kraków: Wydawnictwo Scriptum.

Maleńczyk, I., Gładysz, B. (2019). Academic E-learning in Poland Results of a Diagnostic Survey. International Journal of Research in E-learning IJREL, 5 (1), s. 35-59. 
Means, B., Bakia, M., Murphy, R. (2014). Learning Online: What Research Tells Us about Whether, When and How. New York: Routledge.

Mokwa-Tarnowska, I. (2017). E-learning i blended learning w nauczaniu akademickim. Zagadnienia metodyczne. Gdańsk: Politechnika Gdańska.

Piwowarska, E. (2020). Nauczanie po pandemii: szansa na wprowadzenie ważnych zmian w dydaktyce akademickiej. W: Nauczanie po pandemii. Nowe pytania czy nowe odpowiedzi na stare pytania? (s. 117-123). Warszawa: Instytut Problemów Współczesnej Cywilizacji im. Marka Dietricha.

Plebańska, M. (2020). Cyfrowa edukacja - potencjał, procesy, modele. W: J. Pyżalski (red.), Edukacja w czasach pandemii wirusa COVID-19. Z dystansem o tym, co robimy obecnie jako nauczyciele. Warszawa: EduAkcja.

Plebańska, M., Szyller, A., Sieńczewska, M. (2020). Edukacja zdalna w czasach COVID-19. Raport z badania. Warszawa: Wydział Pedagogiczny Uniwersytetu Warszawskiego.

Ptaszek, G., Bigaj, M., Dębski, M., Pyżalski, J., Stunża, G. D. (2020). Zdalna edukacja gdzie byliśmy, dokąd idziemy? Wstępne wyniki badania naukowego „Zdalne nauczanie a adaptacja do warunków społecznych w czasie epidemii koronawirusa”. Pobrane z: https://zdalnenauczanie.org/wp-content/uploads/2020/06/Badanie-zdalnenauczanie_org_prezentacja.pdf.

Robertson, S. L. (2020). Digital Pedagogy for the 21st Century Educator. W: Handbook of Research on Innovative Pedagogies and Best Practices in Teacher Education (s. 258-275). Hershey: IGI Global.

Schleicher, A. (2020). The impact of COVID-19 on education - Insights from "Education at a Glance 2020”. Warszawa: OECD Publishing. Pobrane z: https://www.oecd.org/ education/the-impact-of-covid-19-on-education-insights-education-at-aglance-2020. pdf.

Stronge, J. H. (2010), Effective teachers = student achievement: What the research says. New York: Routledge.

Sułkowski, Ł. (2020). Covid-19 Pandemic; Recession, Virtual Revolution Leading to De-globalization? Journal of Intercultural Management, 12, 1, s. 1-11. DOI 10.2478/ joim-2020-0029.

Topol, P. (2020). Metody i narzędzia kształcenia zdalnego w polskich uczelniach w czasie pandemii COVID-19 - Część 2, Rekomendacje. Studia Edukacyjne, 59, s. 103-117. DOI: $10.14746 /$ se.2020.59.8.

UNESCO (2020). Education: From Disruption to Recovery. Pobrane z: https://en.unesco. org/covid19/educationresponse.

Urbaniec, J., (2020). Edukacja „pandemiczna”, czyli o kształceniu zdalnym na uczelniach. Forum Akademickie, 05. Pobrane z: https://miesiecznik.forumakademickie.pl/czasopisma/fa-05-2020/edukacja-pandemiczna\%E2\%80\%A8czyli-o-ksztalceniu-zdalnymna-uczel-niach\%E2\%80\%A9/.

Zahorska, M. (2020). Sukces czy porażka zdalnego nauczania? Warszawa: Fundacja im. Stefana Batorego. Pobrane z: https://www.batory.org.pl/wp-content/uploads/2020/09/ Sukces-czy -porazka-zdalnego-nauczania.pdf. 